\title{
Kewenangan Penerapan Aturan Terhadap Tindak Pidana Asusila Yang Korbannya Anak
}

\author{
Muhammad Rhazi, Iskandar A Gani, Dahlan \\ Rhazi421@gmail.com \\ Universitas Syiah Kuala
}

\begin{abstract}
Keywords: $\quad$ Abstract
Aceh; Immoral; This study aims to explain the handling of cases of immoral crimes whose victims are Disparity. children in relation to the determination of the court to try and the authority of the investigation carried out by the National Police Investigators and the Aceh Wilayatul Hisbah Investigators associated with the concept of legal protection. The research method used is juridical empirical. Juridical research is using a statutory approach (dass sollen), while empirical research uses a field/interview approach (dass sein). The results of the study show that in Aceh Province in handling immoral crimes in which the perpetrators and victims are children, 2 (two) laws and regulations are applied, namely Law Number 35 of 2014 concerning Amendments to Law Number 23 of 2002 concerning Child Protection and Aceh Qanun Number 6 of 2014 concerning Jinayat Law. Qanun jinayat is a positive law which in its application still requires higher legislation with the aim of being guided by the scope of the judiciary so that the ideal concept can be clearly seen in handling cases related to jinayat law. Meanwhile, the Qanun jinayat is a derivative of Law Number 11 of 2006 concerning the Government of Aceh.
\end{abstract}

\section{Kata Kunci: \\ Aceh; Asusila; Disparitas.}

\begin{abstract}
Abstrak
Penelitian ini bertujuan untuk menjelaskan penanganan perkara tindak pidana asusila yang korbannya anak kaitannya dengan penentuan pengadilan yang mengadili dan wewenang penyidikan yang dilakukan oleh Penyidik Polri dan Penyidik Wilayatul Hisbah Aceh dikaitkan dengan konsep perlindungan hukum. Adapun metode penelitian yang digunakan bersifat yuridis empiris. Penelitian yuridis adalah menggunakan pendekatan peraturan perundangundangan (dass sollen), sedangkan penelitian empiris menggunakan pendekatan lapangan/wawancara (dass sein). Hasil penelitian bahwa di Provinsi Aceh dalam penanganan tindak pidana asusila yang pelaku maupun korbannya anak diterapkan 2 (dua) aturan perundang-undangan yaitu Undang-undang Nomor 35 Tahun 2014 tentang Perubahan Atas Undang-undang Nomor 23 Tahun 2002 tentang Perlindungan Anak dan Qanun Aceh Nomor 6 Tahun 2014 tentang Hukum Jinayat. Qanun jinayat merupakan hukum positif yang dalam penerapannya masih memerlukan peraturan perundang-undangan yang lebih tinggi dengan tujuan untuk dipedomani oleh lingkup peradilan sehingga dapat dilihat secara jelas konsep ideal dalam penanganan perkara yang berkaitan dengan hukum jinayat. Sedangkan Qanun jinayat tersebut merupakan turunan dari Undang-undang Nomor 11 Tahun 2006 tentang Pemerintah Aceh.
\end{abstract}


Muhammad Rhazi, dkk: Kewenangan Penerapan Aturan...

\section{Pendahuluan}

Aceh merupakan satuan pemerintahan daerah yang bersifat khusus atau istimewa terkait dengan salah satu karakter khas sejarah perjuangan masyarakat Aceh yang memiliki ketahanan dan daya juang tinggi tersebut bersumber dari pandangan hidup yang berlandaskan syari'at Islam yang melahirkan budaya Islam yang kuat.

Di sisi lain, formalisasi syari'at Islam yang pernah diperjuangkan di level nasional dahulu saat ini terus bergulir dan bergeser ke tingkat daerah karena di tataran nasional dianggap tidak menemui jalan mulus, apalagi didukung dengan konsepsi otonomi daerah yang menjadi lebih luas pasca reformasi. ${ }^{1}$

Kasus yang terjadi di lapangan adanya tindak pidana asusila yang terjadi di wilayah hukum Kabupaten Aceh Besar yang dilakukan oleh TMJ (57) terhadap korban yang bernama RR (25). Kemudian kasus yang terjadi di wilayah hukum Kota Banda Aceh yang dilakukan oleh RN (28) terhadap AA (13), SB (40) terhadap PN (10) dan RV (16) terhadap anak CP (15).

Dari uraian diatas terdapat 2 (dua) aturan hukum yang berlaku yaitu aturan hukum pada Undang-undang Nomor 35 Tahun 2014 tentang Perubahan Atas Undang-undang Nomor 23 Tahun 2002 tentang Perlidungan Anak dan Undang-Undang Nomor 17 Tahun 2016 tentang Penetapan Peraturan Pemerintah Pengganti Undang-undang Nomor 1 Tahun 2016 tentang Perubahan Kedua Atas Undang-undang Nomor 23 Tahun 2002 tentang Perlindungan Anak menjadi undang-undang. Kemudian juga diatur dalam Qanun Aceh Nomor 6 Tahun 2014 tentang Hukum Jinayat (Qanun Jinayat).

Berdasarkan uraian kasus sebagaimana yang telah diuraikan diatas, maka permasalahannya adalah bagaimana penanganan perkara tindak pidana asusila yang korbannya anak dengan penentuan pengadilan yang mengadili dan bagaimanakah konsep ideal terkait dengan wewenang penyidikan yang dilakukan oleh Penyidik Polri dan Penyidik Pegawai Negeri Sipil (PPNS) Wilayatul Hisbah Aceh dikaitkan dengan konsep perlindungan hukum.

\footnotetext{
${ }^{1}$ Endri, 'Analisis Yuridis Terhadap Legalitas Qanun Aceh No. 6/2014 Tentang Hukum Jinayat’ (2018) 1 Kanun Jurnal Ilmu Hukum.[1].
} 
Suatu kerangka pikir atau kerangka teori bertujuan untuk menyajikan cara untuk mengorganisasikan dan menginterpretasikan hasil penelitian dan menghubungkannya dengan hasil penelitian. ${ }^{2}$ Teori hukum yang digunakan dalam penulisan ini adalah Teori Negara Hukum sebagai grand theory, selanjutnya digunakan teori Kewenangan sebagai middle theory, teori Perlindungan Hukum sebagai applied theory.

Adapun metode penelitian yang digunakan bersifat yuridis empiris. Penelitian yuridis adalah menggunakan pendekatan peraturan perundangundangan (das sollen), sedangkan penelitian empiris menggunakan pendekatan lapangan/wawancara (das sein).

\section{Metode Penelitian}

Metode penelitian yang bersifat yuridis empiris. Penelitian yuridis adalah menggunakan pendekatan peraturan perundang-undangan (dass sollen), sedangkan penelitian empiris menggunakan pendekatan lapangan/wawancara (dass sein).

Metode pendekatan yang digunakan yaitu penelitian sosiolegal (Socio Legal Research) yang menitiberatkan perilaku individu atau masyarakat dalam kaitannya dengan hukum. Berdasarkan hal tersebut, tidak dapat disangkal bahwa yang paling sering menjadi topik di dalam penelitian sosiolegal adalah masalah efektivitas aturan hukum, kepatuhan terhadap aturan hukum, peranan lembaga atau institusi hukum dalam penegakan hukum, implementasi aturan hukum, pengaruh aturan hukum terhadap masalah sosial tertentu atau sebaliknya, pengaruh masalah sosial tertentu terhadap hukum. ${ }^{3}$

\section{Kewenangan Penanganan Perkara}

Dalam Undang-undang Nomor 8 Tahun 1981 tentang Hukum Acara Pidana (KUHAP) pada Pasal 1 ayat (1) disebutkan bahwa "Penyidik adalah pejabat Polisi

\footnotetext{
${ }^{2}$ Burhan Ashofa, Metode Penelitian Hukum (Rineke Cipta 1998).[23].

${ }^{3}$ Peter Mahmud Marzuki, Penelitian Hukum (Kencana 2016).[123].
} 
negara Republik Indonesia atau pejabat pegawai negeri sipil tertentu yang diberi wewenang khusus oleh undang-undang untuk melakukan penyidikan". ${ }^{4}$

Sedangkan pada Pasal 1 ayat (2) disebutkan bahwa "Penyidikan adalah serangkaian tindakan penyidik dalam hal dan menurut cara yang diatur dalam undang-undang ini untuk mencari serta mengumpulkan bukti yang dengan bukti itu membuat terang tentang tindak pidana yang terjadi dan guna menemukan tersangkanya".

Menurut M. Yahya Harahap, “penyelidikan” merupakan tindakan tahap pertama permulaan "penyidikan". Akan tetapi harus diingat, penyelidikan bukan tindakan yang berdiri sendiri terpisah dari fungsi "penyidikan". Penyelidikan merupakan bagian yang tak terpisah dari fungsi penyidikan. ${ }^{5}$

Sesuai Peraturan Kapolri No. Pol. : 10 tahun 2007 tentang Organisasi dan Tata Kerja Unit Pelayanan Perempuan dan Anak (unit PPA) di Lingkungan Kepolisian Negara Republik Indonesia, disebutkan unit PPA adalah Unit yang bertugas memberikan pelayanan, dalam bentuk perlindungan terhadap perempuan dan anak yang menjadi korban kejahatan dan penegakan hukum terhadap pelakunya.

Selanjutnya pada pasal6 ayat (3) disebutkan secara tegas bahwa “Lingkup tugas Unit PPA meliputi tindak pidana terhadap perempuan dan anak, yaitu; perdagangan orang (human trafficking), penyelundupan manusia (people smuggling), kekerasan (secara umum maupun dalam rumah tangga), susila (perkosaan, pelecehan, cabul), vice (perjudian dan prostitusi), adopsi ilegal, pornografi dan pornoaksi, money laundering dari hasil kejahatan tersebut di atas, masalah perlindungan anak (sebagai korban/tersangka), perlindungan korban, saksi, keluarga dan teman serta kasuskasus lain dimana pelakunya adalah perempuan dan anak".

Lebih lanjut Yahya Harahap menyatakan bahwa jadi sebelum dilakukan tindakan penyidikan, dilakukan dulu penyelidikan oleh pejabat penyelidik, dengan maksud dan tujuan mengumpulkan "bukti permulaan" atau "bukti yang

\footnotetext{
${ }^{4}$ Undang-Undang Nomor 8 Tahun 1981 tentang Kitab Undang-undang Hukum Acara Pidana (Lembaran Negara Republik Indonesia Tahun 1981 Nomor 76).

${ }^{5}$ M. Yahya Harahap, Pembahasan Permasalahan Dan Penerapan KUHP Penyidikan Dan Penuntutan (Ghalia 2007).[101].
} 
cukup" agar dapat dilakukan tindak lanjut penyidikan. Mungkin penyelidikan dapat disamakan dengan pengertian "tindak pengusutan" sebagai usaha mencari dan menemukan jejak berupa keterangan dan bukti-bukti suatu peristiwa yang diduga merupakan tindak pidana. ${ }^{6}$

Penyidik Unit PPA yang menangani perkara anak wajib merahasiakan identitas anak atau hal-hal lain yang dapat mengungkapkan jati diri anak yang berhadapan dengan hukum (dalam hal pemberitaan dimedia cetak ataupun elektronik), sehingga menghindari labelisasi atau stigmatisasi terhadap anak. Ini mencerminkan perlindungan hukum terhadap anak yang berhadapan dengan hukum.?

Polisi merupakan salah satu profesi office nobile, profesi mulia dan terhormat. Setiap negara di belahan dunia manapun, membutuhkan polisi untuk melayani dan melindungi masyarakat dari segala macam kejahatan serta gangguan keamanan dan ketertiban lainnya. ${ }^{8}$

Kepolisian diberikan kewenangan atau diskresi oleh hukum pidana kita untuk melakukan seluruh rangkaian proses terhadap siapa saja yang terlibat dalam kejahatan19. Wewenang kepolisian bukanlah untuk mempengaruhi jalannya proses pemidanaan, namun untuk memperkuat proses penegakan hukum. ${ }^{9}$

Pengaturan mengenai penyelidikan dan penyidikan di tingkat kepolisian diatur di dalam Kitab Undang-Undang Hukum Acara Pidana, kemudian dijelaskan dalam Perkap Nomor 14 Tahun 2012 tentang Manajemen Penyidikan Tindak Pidana. Penyidikan tindak pidana tersebut harus dilaksanakan dengan professional, transparan dan akuntabel terhadap setiap perkara pidana, guna terwujudnya supremasi hukum yang mencerminkan rasa keadilan. ${ }^{10}$

${ }^{6}$ ibid.

7 Bayu Riza Arifyanto, 'Proses Penyidikan Terhadap Anak Pelaku Tindak Pidana Penganiayaan Di Unit Pelayanan Perempuan Dan Anak Kepolisian Resort Pati' Konferensi Ilmiah Mahasiswa Unissula, (2019).[1].

${ }^{8}$ Ronny Nitibaskara, Kapita Selekta Sosiologi Kepolisian (UM Jakarta Press 2018).[30].

${ }^{9}$ Eva Achjani Zulfa \& Sri B Praptadina, 'Diskresi Kepolisian Dalam Penanganan Konflik Sosial:Kedudujan Peraturan Internal Kepolisian Dalam Penanganan Konflik Di Dalam Peraturan Perundang-Undangan' (2016) 46 Jurnal Hukum \& Pembangunan.[544-545].

${ }^{10}$ Rena Yulia, 'Perlindungan Hukum Terhadap Korban Kejahatan Pada Proses Penyelidikan Dan Penyidikan Dalam Sistem Peradilan Pidana' (2019) 3 Jurnal Hukum \& Pembangunan.[663]. 
Proses penyidikan ini, tentu saja akan melibatkan korban, dan keterlibatan korban dalam proses pencarian alat bukti seringkali hanya dijadikan sebagai saksi. Saksi adalah orang yang dapat memberikan keterangan guna kepentingan penyidikan, penuntutan dan peradilan tentang suatu perkara pidana yang didengar, dilihat dan atau dialami sendiri. Penempatan korban sebagai saksi korban dalam proses penyidikan menjadikan posisi korban kurang mendapatkan perlindungan hukum yang memadai.

Penyidik Polri melalui Unit PPA dan PPNS Satpol PP dan Wilayatul Hisbah berwenang untuk menangani perkara asusila, akan tetapi berdasarkan data respon diatas diketahui bahwa PPNS Satpol PP dan Wilayatul Hisbah Aceh tidak pernah menangani perkara yang menyangkut anak dikarenakan belum mendapatkan surat keputusan dari Gubernur Aceh dan selama ini selalu dilimpahkan ke Polda Aceh.

Kemudian kewenangan Pejabat PPNS adalah Menerima laporan atau pengaduan dari seorang tentang adanya tindak pidana, melakukan tindakan pertama pada saat ditempat kejadian, menyuruh berhenti seseorang tersangka dan memeriksa tanda pengenal diri tersangka, melakukan penangkapan, penahanan, penggeledahan, dan penyitaan, melakukan pemeriksaan dan penyitaan surat, mengambil sidik jari dan memotret seseorang, memanggil orang untuk didengar dan diperiksa sebagai tersangka atau saksi, mendatangkan orang ahli yang diperlukan dalam hubunganya dengan pemeriksaan perkara, mengadakan penghentian penyidikan dan mengadakan tindakan lain menurut hukum yang bertanggung jawab.

Asas legalitas dalam Hukum Admnistrasi Negara, bahwa semua perbuatan dan keputusan pejabat administrasi harus didasarkan pada kewenangan yang diberikan oleh peraturan perundang-undangan, Jika tidak adanya norma dan atau norma tersamar, asas kewenangan tersebut menggunakan asas-asa umum pemerintahan yang baik (Principle of Proper Administration). ${ }^{11}$

11 Yudistira Rusydi, 'Wewenang Dan Hambatan Penyidik Pegawai Negeri Sipil Satuan Pamong Praja Dalam Pelaksanaan Upaya Paksa Terhadap Pelanggaran Kasus Asusila' (2014) 2 Pendecta 229. 
Pada saat proses penyelidikan dan penyidikan, penyidik menjalankan tugas atas arahan pimpinan terkait dengan aturan hukum mana yang akan diterapkan dikarenakan berdasarkan temuan dilapangan atau laporan masyarakat.Selanjutnya apabila korbannya anak dan pelakunya anak yang perbuatannya khalwat/mesum dan bukan karena paksaan maka atas perbuatan tersebut dapat diterapkan qanun aceh tentang jinayat, namun jika perbuatan dilakukan atas dasar bujuk rayu dan pemaksaan mengakibatkan pihak korban dirugikan maka diterapkan undangundang perlindungan anak.

Selanjutnya apabila yang korbannya anak dan pelakunya adalah dewasa dengan cara perbuatannya tidak bersifat bujuk rayu, pemaksaan, pengancaman dan tidak berdaya maka terhadap pelaku asusila tersebut diterapkan undangundang perlindungan anak, namun apabila perbuatannya bersifat bujuk rayu, pemaksaan, pengancaman dan tidak berdaya maka terhadap pelaku asusila diterapkan Qanun Aceh tentang Hukum Jinayat.

Kemudian pada saat pembuktian berkas perkara sangat bergantung pada keterangan korban dan saksi-saksi lainnya yang bersesuaian dengan alat bukti lainnya, sehingga dari keseseuaian alat bukti tersebut dapat menyakinkan dan menyatakan bahwa telah terjadi perbuatan asusila dengan bujukrayu atau ancaman kekerasan, dan dibutuhkan alat bukti surat/Visum Et Repertum untuk menyatakan yang bahwa perbuatan pelaku asusila adalah suatu perbuatan kekerasan, sehingga setelah berkas perkaranya lengkap untuk diajukan kepada Jaksa Penuntut Umum (JPU).

Setelah menerima berkas dari Penyidik, Jaksa Penuntut Umum meneliti kelengkapan berkas dengan berpedoman pada syarat formil yaitu berkaitan dengan kelengkapan surat-surat dalam berkas dan syarat materil yaitu berkaitan dengan dengan pemenuhan unsur-unsur yang dipersangkakan dengan uraian fakta perbuatan yang diuraikan oleh Penyidik" dan mengedepankan penerapat Qanun yang merupakan telah menjadi hukum positif di Propinsi Aceh.

Dalam pemeriksaan anak yang berhadapan dengan hukum harus didampingi oleh orang tua/wali, Lembaga Penempatan Anak Sementara (LPAS) 
Muhammad Rhazi, dkk: Kewenangan Penerapan Aturan...

merupakan tempatsementara bagi Anak yang Berhadapan dengan Hukum $(\mathrm{ABH})$ selama menjalani proses peradilan penahanan dan Dimana Balai Pemasyarakatan (BAPAS) merupakan bagian dari sistem Tata Peradilan, mempunyai tugas melaksanakan pembimbing dan mendampingi anak yang berhadapat dengan hukum dalam proses Peradilan Anak serta pebinaan kepada anak tersebut serta Lembaga Penyelenggaraan Kesejahteraan Sosial (LPKS) adalah lembaga atau tempat pelayanan sosial yang melaksanakan penyelenggaraan kesejahteraan sosial bagi Anak, hal tersebut berlaku pada setiap tingkatan pemeriksaan yaitu tingkat Penyidik, Penuntut Umum dan Hakim, dan dalam pemeriksaan anak yang berhadapan dengan hukum harus tetap diupayakan diversi disetiap tingkatan tersebut.

Penerapan aturan perundang-undangan terhadap pelaku asusila anak seharusnya menggunakan aturan Qanun Aceh tentang hukum jinayat, namun apabila dalam keadaan mendesak maka dapat digunakan undang-undang perlindungan anak. Ada beberapa kasus yang ditangani yaitu pelaku asusila dan korbannya adalah anak dilakukan diversi di tingkat Polda Aceh dengan hukum harus bisa membaca Al-Quran selama 3 (tiga) bulan.

Kemudian hukuman cambuk tidak dapat memberikan efek jera terhadap pelaku tindak pidana asusila namun harus disertakan dengan hukuman badan yaitu penjara karena hukuman cambuk dan hukuman badan dapat memberikan pelajaran terhadap pelaku asusila. Bahwa untuk kedepannya penerapan kedua aturan hukum tersebut dapat berjalan sebagaimana mestinya. Pelaku asusila sering terjadi dilakukan oleh orang-orang terdekat korban dikarenakan faktor sering menonton konten-konten pornografi.

Bahwa untuk 1 (satu) kasus dapat diterapkan 2 (dua) aturan yaitu undangundang tentang perlindungan anak dan Qanun Aceh tentang hukum jinayat, akan tetapi dalam 1 (satu) berks tidak dapat digabung aturan hukum tersebut dikarenakan menyangkut dengan kompetensi peradilan yang mengadili akan tetapi dalam kasus yang serupa dapat diterapkan aturan hukum yaitu undangundang perlindungan anak dan Qanun Aceh tentang hukum jinayat. 
Selanjutnya sehubungan dengan Surat Edaran (SE) Jaksa Agung Republik Indonesia Nomor : SE-2/E/Ejp/11/2020 tentang Pedoman Penanganan Perkara Tindak Pidana Umum dengan Hukum Jinayat Di Provinsi Aceh, pada saat pelimpahan berkas perkara atau yang dikenal dengan tahap I maka Penuntut Umum (Jaksa Peneliti Berkas Perkara) sedapat mungkin memberikan petunjuk untuk menerapkan Qanun Jinayat jika perbuatan melawan hukum tersebut telah diatur didalam Qanun Aceh, dengan tetap menerapkan Sistem Peradilan Anak.

Surat Edaran (SE) Jaksa Agung Republik Indonesia Nomor : SE-2/E/ Ejp/11/2020 tentang Pedoman Penanganan Perkara Tindak Pidana Umum Dengan Hukum Jinayat Di Provinsi Aceh asarkan Undang-Undang No. 11 Tahun 2006 tentang Pemerintahan Aceh ("UU Pemerintahan Aceh”), Pemerintah Aceh diberikan beberapa kewenangan istimewa dalam mengurus daerahnya.

Keputusan Ketua Mahkamah Agung RI Nomor: KMA/070/SK/X/2004 tanggal 06 Oktober 2004 tentang Pelimpahan sebagaian Kewenangan dari Peradilan Umum Kepada Mahkamah Syar'iyah di Provinsi Nanggroe Aceh Darussalam yang menyatakan bahwa Melimpahkan sebagian kewenangan dan Peradilan Umum di Provinsi Nanggroe Aceh Darussalam kepada Mahkamah Syari'ah di Provinsi Nanggroe Aceh Darussalam perkaraperkara Jinayah bagi subjek hukum yang beragama Islam dalam perkara-perkara yang telah ditetapkan dalam Qanun Provinsi Nanggroe Aceh Darussalam.

Mekanisme penyidikan oleh Pejabat Penyidik Pegawai Negeri Sipil (PPNS) bersesuain dengan teori negara hukum, teori kewenangan dan teori perlindungan hukum. Teori kewenangan diperuntukkan kepada penyidik pada saat melakukan penyidikan kewenangannya diberikan oleh Undang-undang Nomor 8 Tahun 1981 tentang Kitab Undang-undang Hukum Acara Pidana dan Qanun Aceh Nomor 12 Tahun 2012 tentang Penyidik Pegawai Negeri Sipil, sedangkan bagi Jaksa Penuntut Umum/Jaksa Peneliti juga harus memperhatikan Surat Edaran (SE) Jaksa Agung Republik Indonesia Nomor : SE-2/E/Ejp/11/2020 tentang Pedoman Penanganan Perkara Tindak Pidana Umum Dengan Hukum Jinayat Di Provinsi Aceh. 
Muhammad Rhazi, dkk: Kewenangan Penerapan Aturan...

Bagi Mahkamah Syar'iyah sudah berseuaian dengan Keputusan Presiden (KEPPRES) tentang Mahkamah Syar'iyah Dan Mahkamah Syar'iyah Provinsi Di Provinsi Nanggroe Aceh Darussalam Nomor 11 Tahun 2003 tentang Mahkamah Syar'iyah dan Mahkamah Syar'iyah Provinsi Nanggroe Aceh Darussalam dan Keputusan Ketua Mahkamah Agung RI Nomor: KMA/070/SK/X/ 2004 tanggal 06 Oktober 2004 tentang Pelimpahan sebagaian Kewenangan dari Peradilan Umum Kepada Mahkamah Syar'iyah di Provinsi Nanggroe Aceh Darussalam.

\section{Konsep Ideal Kewenangan Penyidikan Penyidik Polri dan Penyidik Wilayatul Hisbah Yang Dikaitkan Dengan Konsep Perlindungan Hukum}

Qanun di Aceh khususnya hukum jinayat terdapat pengaturanya dalam peraturan perundang-undangan sebagai berikut: dalam UU No. 18 Tahun 2001 tentang Otonomi Khusus Bagi Provinsi Daerah Istimewa Aceh Sebagai Provinsi Nanggroe Aceh Darussalam. Kedudukan Qanun terdapat di dalam Pasal 1 angka 8 yang mengatakan bahwa "Qanun Provinsi NAD adalah peraturan daerah sebagai pelaksanaan undang-undang di wilayah Provinsi NAD dalam rangka penyelenggaraan otonomi khusus".

Undang-undang Nomor 11 Tahun 2012 tentang Pembentukan Peraturan Perundang undangan. Penjelasan Pasal 7 ayat (2) a, yang mengatakan bahwa: Termasuk dalam jenis peraturan daerah provinsi adalah Qanun yang berlaku di Aceh dan perdasus serta perdasi yang berlaku di propinsi Papua, kemudian dalam UU Pemerintahan Aceh, Pasal 21 dan Pasal 22 undang-undang Pemerintahan Aceh menyatakan bahwa "Qanun adalah peraturan perundang-undangan sejenis peraturan daerah yang mengatur penyelenggaraan pemerintahan dan kehidupan masyarakat Aceh".

Qanun Jinayat merupakan kesatuan hukum pidana yang berlaku bagi masyarakat Aceh yang dibentuk berdasarkan nilai-nilai syari'at Islam. Qanun Jinayat mengatur tentang Jarimah (perbuatan yang dilarang oleh syariat Islam), pelaku jarimah, dan uqubat (hukuman yang dapat dijatuhkan oleh hakim terhadap pelaku jarimah). 
Salah satu bentuk hukuman yang dapat dijatuhkan kepada pelaku jarimah berdasarkan Qanun Jinayat adalah hukuman cambuk. Pada praktiknya, hukuman cambuk ini dilakukan di depan khalayak ramai yang bertujuan untuk mempermalukan pelaku jarimah di depan masyarakat. Dalam Qanun Jinayat, hukuman cambuk dikenakan mulai dari 10 kali sampai 200 kali tergantung dengan tindak pidana yang dilakukan. Selain itu, terdapat juga beberapa ketentuan yang menduplikasi ketentuan-ketenuan yang sudah diatur pada Kitab Undang-Undang Hukum Pidana namun dengan sanksi pidana yang lebih eksesis.

Sanksi hukuman cambuk bukanlah suatu sanksi pidana yang dikenal di Indonesia karena Kitab Kitab Undang-Undang Hukum Pidana telah mengatur secara limitatif jenis sanksi pidana apa saja yang dapat dikenakan terhadap tindak pidana. Pemerintah Aceh berdasarkan UU Pemerintahan Aceh tidak memiliki kewenangan untuk menciptakan suatu bentuk sanksi pidana baru, apalagi suatu bentuk hukuman yang jauh lebih berat dari yang sudah ditetapkan oleh Kitab Undang-Undang Hukum Pidana.

Selain itu, penggunaan hukuman cambuk merupakan langkah mudur ditengah semangat negara dalam melindungi hak asasi manusia. Hukuman cambuk tergolong hukuman yang kejam, tidak manusiawi, dan merendahkan martabat manusia. Hal ini bertentangan dengan beberapa ketentuan perundanganundangan di atas Qanun Jinayat.

Pada dasarnya pembentukan Qanun Aceh tentang Hukum Jinayat tujuannya adalah untuk pembinaan karakter terhadap pelaku, maka dari itu pentingnya peran aparatur gampong/desa untuk dihadirkan pada setiap tindakan sehingga pada saat pengambilan keputusan dapat memberikan keputusan yang dirasa adil baik terhadap pelaku maupun terhadap korban. Bahkan lebih jauh tujuan dari pembentukan dan penerapan syari'at islam dengan diberlakukan Qanun Jinayat ditujukan untuk pembentukan akhlak masyarakat aceh menjadi lebih baik.

Perlindungan hukum terhadap korban kejahatan dalam tahap penyidikan di kepolisian telah diatur dalam beberapa peraturan kepolisian, antara lain peraturan kapolri dan surat edaran. Akan tetapi pelaksanaan dari aturan tersebut belum 
dapat dilaksanakan secara menyeluruh, mengingat beberapa peraturan tersebut dikhususkan untuk tindak pidana tertentu, bukan untuk semua tindak pidana.

Perspektif perlindungan yang diberikan berdasar atas kebutuhan negara terhadap keterangan saksi, bukan karena dilihat sebagai partisipasi warga negara karena jasa/sumbangsihnya memberikan keterangan saksi sehingga perlu dilindungi. Demikian halnya terhadap korban, masih melihat korban perlu dilindungi karena negara membutuhkan keterangannya, bukan karena negara merasa bertanggungjawab atas kegagalannya melindungi warganya. ${ }^{12}$

Beberapa hak-hak korban di atas mungkin tidak berkaitan langsung dengan tugas dan kewenangan kepolisian dalam hal penyidikan. Beberapa hak di atas, menjadi pertanyaan penyidik, apakah memang harus diberikan oleh penyidik atau ada sub sistem peradilan lain yang memiliki tugas dan kewenangan tersebut.

Hak untuk mendapatkan informasi mengenai putusan pengadilan, hak untuk mendapatkan informasi dalam hal terpidana dibebaskan, hak dirahasiakan identitasnya, Hak untuk mendapat identitas baru, adalah merupakan hak-hak korban yang diperoleh bukan pada tahap penyidikan, sehingga tidak menjadi kewenangan penyidik untuk pemenuhan hak-hak tersebut.

Hak dirahasiakan identitasnya dapat juga diperoleh di tahap penyidikan. Hak ini merupakan hak baru yang ada dalam perubahan undang-undang perlindungan saksi dan korban.

Adapun hak-hak korban lainnya adalah mendapat tempat kediaman sementara; mendapatkan tempat kediaman baru; memperoleh penggantian biaya transportasi sesuai dengan kebutuhan; mendapatkan nasihat hukum; dan/atau; memperoleh bantuan biaya hidup sementara sampai waktu perlindungan berakhir; mendapat pendampingan. Hak-hak tersebut akan sulit di implementasikan dalam tahap penyidikan, apabila hanya penyidik yang melaksanakan. Oleh karenanya diperlukan lembaga lain yang berwenang untuk secara koordinasi memenuhi hak-hak korban.

${ }^{12}$ Nurul Ghufron, 'Meningkatkan Peran LPSK Sebagai Pendorong Perubahan Paradigma Dari Alat Bukti Menusu Partisipasi Dalam Sistem Peradilan Anak' (2013) 1 Jurnal Perlindungan.[82]. 
Melihat prinsip-prinsip di atas, sesungguhnya sejalan dengan hak-hak korban yang harus dipenuhi. Namun, Perkap ini memang ditujukan untuk korban perempuan dan/atau anak, tetapi tidak ada salahnya jika diterapkan kepada seluruh korban tindak pidana.

Bahwa untuk mengatasi berkurangnya akhlak, maka aturan Qanun Jinayat tersebut harus memuat 2 (dua) komponen yaitu pembinaan dan penindakan, namun kedua kompenen tersebut juga tidak akan berjalan maksimal apabila tidak dilakukannya pembinaan akhlak terhadap pelaku sehingga tujuan dibentuknya aturan tersebut adalah untuk dijadikan pembelajaran/tadabbur.

Dalam ini memang harus diakui bahwasanya Qanun tersebut belum sepenuhnya diterapkan hal ini disebabkan oleh berbagai faktor baik itu dari unsur pemerintah maupun dari masyarakat aceh sendiri, yang masih beranggapan yang bahwa Qanun tersebut terlalu kejam dan mundur, tetapi kita tidak boleh berhenti disitu karena Qanun tersebut harus bisa dilaksanakan untuk mencapai Aceh yang madani dan islami serta berakhlak mulia.

Sehingga dari data kasus diatas bisa dikatakan benar kata masyarakat yang berkembang yaitu bisa-bisa diatur untuk penerapan aturan yang ada, sehingga ada penilaian kalua mau cepat pakai Qanun akan tetapi kalua tidak dikondisikan bisa berujung penerapan Undang-undang perlindungan anak, dimana arahnya bakal diproses melalui PN dan kemudian ujung-ujungnya akan di penjara, sedangkan jika digunakan cambuk cukup sebentar dan sudah bisa bebas lagi.

Maka dari pada itu seharusnya penerapan qanun itu sendiri sebenarnya sudah ada mengatur mengenai penjara dan tidak serta merta jika menggunakan qanun sudah pasti cambuk, sehingga mulai dari proses penuntutan JPU sudah seyogyanya menuntut penjara walaupun dengan menggunakan instrumen qanun dan hakim pun sedapat mungkin atas keyakinan dan pertimbangan dapat memutuskan hukuman penjara, sehingga bisa ditepis pemahaman yang sudah dibangun oleh masyarakat untuk sekarang yang bahwa qanun tersebut tidak sesuai lagi.

Kemudian dalam penerapan Qanun Aceh Nomor 6 Tahun 2014 tentang Hukum Jinayat, bagi pelaku tindak pidana asusila yang korbannya anak 
seyogyanya dapat diterapkan Qanun tersebut karena didalam Qanun sudah diatur terkait dengan hukuman terhadap pelaku baik itu hukuman cambuk maupun penjara dan adanya restitusi terhadap anak sebagai korban berupa pembayaran denda sehingga walaupun perkara tersebut ditangani oleh unit PPA yang penerapan aturannya menggunakan Qanun jinayat maka pada saat persidangan wajib dilaksanakan oleh Mahkamah Syar'iah.

Tentunya kekurangan tersebut harus bisa di perbaiki khususnya oleh Pemerintah untuk memberikan sarana dan prasarana untuk menunjang pelaksanaan qanun tersebut dan yang sangat penting adalah peran serta tokoh masyarakat dan pemuka agama, sehingga apa yang diinginkan oleh qanun itu sendiri bisa tercapai.

Maka sudah seyogyanya setiap pelanggar ketentuan khususnya tindak pidana asusila yang korbanya anak bisa diterapkan dengan menggunakan instrumen qanun yang tetap memperhatikan sistem peradilan anak, sehingga terdapat satu pemahaman yang sama tentang penerapan hukum yang harus diberlakukan di Aceh, selanjutnya berkaitan dengan penerapan ancaman hukum yang aka digunakan, di qanun sendiri terdapat berbagai macam pilihan hukum yang bisa diambil oleh hakim dalam memutuskan perkara baik itu setelah melalui pertimbangan hakim memutuskan cambuk.

Kemudian tidak tertutup kemungkinan setelah melalui proses pertimbangan maka hakim bisa mengambil keputusan untuk amar hukumannya adalah penjara. Dan juga Idealnya juga seharisnya Polisi RI mengeluarkan semacam aturan juga untuk hal tersebut sehingga terjadi keseragaman pemberlakuaan aturan hukum di Aceh untuk mengedepankan penerapan Qanun.

\section{Kesimpulan}

Perbuatan asusila adalah suatu perbuatan pidana, khususnya di Provinsi Aceh terdapat 2 (dua) aturan hukum yang berlaku yaitu aturan hukum pada Undang-undang Perlidungan Anak dan Qanun Aceh Hukum Jinayat. Penyidikan terhadap pelaku tindak pidana asusila yang korbannya anak maka dapat diterapkan 
Qanun Aceh Nomor 6 Tahun 2014 tentang Hukum Jinayat, walaupun ada Undang-undang Nomor 35 Tahun 2014 tentang Perubahan Atas Undang-undang Nomor 23 Tahun 2002 tentang Perlidungan Anak dan Undang-Undang Nomor 17 Tahun 2016 tentang Penetapan Peraturan Pemerintah Pengganti Undang-undang Nomor 1 Tahun 2016 tentang Perubahan Kedua Atas Undang-undang Nomor 23 Tahun 2002 tentang Perlindungan Anak menjadi undang-undang, mengingat adanya adanya Surat Edaran (SE) Jaksa Agung Republik Indonesia Nomor : SE2/E/Ejp/11/2020 tentang Pedoman Penanganan Perkara Tindak Pidana Umum Dengan Hukum Jinayat Di Provinsi Aceh asarkan Undang-Undang No. 11 Tahun 2006 tentang Pemerintahan Aceh (“UU Pemerintahan Aceh”), Pemerintah Aceh diberikan beberapa kewenangan istimewa dalam mengurus daerahnya.

Pejabat Penyidik Pegawai Negeri Sipil (PPNS) Satpol PP dan Wilayatul Hisbah mempunyai kewenangan untuk melakukan penyidikan Hukum Jinayat dan mengikuti Hukum Acara Jinayat, dan dalam hal perkara anak yang berkonflik/ berhadapan dengan hukum maka harus menggunakan hukum acara seperti yang ditentukan dalam Sistem Peradilan Anak. Terhadap penerapan aturan yang harus dipergunakan di Propinsi Aceh yang berkaitan dengan kejahatan yang telah diakomudir pada Qanun Jinayah maka sedapat mungkin mengedepankan penerapan Qanun Jinayat karena menurut hemat penulis qanun jinayat tersebut telah jelas menjadi hukum posistif yang harus dikedepankan dalam penanganan kasus Jinayat dan hal tersebut telah ditindalanjuti oleh peraturan perundangundangan untuk pelaksanaan sepenuhnya Hukum Jinayat Di Provinsi Aceh, serta aturan tersebut dapat ditindaklanjuti dengan peraturan yang lebih tinggi agar dapat dipedomani khususnya oleh lingkup peradilan yaitu Mahkamah Syar'iah sehingga dapat dilihat dengan jelas konsep ideal penanganan perkara berkaitan dengan hukum jinayat.

\section{Daftar Bacaan}

Buku

Burhan Ashofa, Metode Penelitian Hukum (Rineke Cipta 1998). 
Muhammad Rhazi, dkk: Kewenangan Penerapan Aturan...

M. Yahya Harahap, Pembahasan Permasalahan Dan Penerapan KUHP Penyidikan Dan Penuntutan (Ghalia 2007).

Peter Mahmud Marzuki, Penelitian Hukum (Kencana 2016).

Ronny Nitibaskara, Kapita Selekta Sosiologi Kepolisian (UM Jakarta Press 2018).

\section{Jurnal}

Endri, 'Analisis Yuridis Terhadap Legalitas Qanun Aceh No. 6/2014 Tentang Hukum Jinayat' (2018) 1 Kanun Jurnal Ilmu Hukum 1.

Eva Achjani Zulfa \& Sri B Praptadina, 'Diskresi Kepolisian Dalam Penanganan Konflik Sosial:Kedudujan Peraturan Internal Kepolisian Dalam Penanganan Konflik Di Dalam Peraturan Perundang-Undangan' (2016) 46 Jurnal Hukum \& Pembangunan 544-545.

Nurul Ghufron, 'Meningkatkan Peran LPSK Sebagai Pendorong Perubahan Paradigma Dari Alat Bukti Menusu Partisipasi Dalam Sistem Peradilan Anak' (2013) 1 Jurnal Perlindungan 82.

Rena Yulia, 'Perlindungan Hukum Terhadap Korban Kejahatan Pada Proses Penyelidikan Dan Penyidikan Dalam Sistem Peradilan Pidana' (2019) 3 Jurnal Hukum \& Pembangunan 663.

Yudistira Rusydi, 'Wewenang Dan Hambatan Penyidik Pegawai Negeri Sipil Satuan Pamong Praja Dalam Pelaksanaan Upaya Paksa Terhadap Pelanggaran Kasus Asusila' (2014) 2 Pendecta 229.

\section{Perundang-undangan}

Undang-Undang Nomor 8 Tahun 1981 tentang Kitab Undang-undang Hukum Acara Pidana (Lembaran Negara Republik Indonesia Tahun 1981 Nomor 76).

Undang-undang Nomor 35 Tahun 2014 tentang Perubahan Atas Undang-undang Nomor 23 Tahun 2002 tentang Perlidungan Anak.

Undang-Undang Nomor 17 Tahun 2016 tentang Penetapan Peraturan Pemerintah Pengganti Undang-undang Nomor 1 Tahun 2016 tentang Perubahan Kedua Atas Undang-undang Nomor 23 Tahun 2002 tentang Perlindungan Anak menjadi undang-undang.

Qanun Aceh Nomor 6 Tahun 2014 tentang Hukum Jinayat (Qanun Jinayat).

How to cite: Muhammad Rhazi, Iskandar A Gani, Dahlan, 'Kewenangan Penerapan Aturan Terhadap Tindak Pidana Asusila Yang Korbannya Anak' (2022) Vol. 5 No. 1 Media Iuris. 